L. VARGA

K. TOMPA

T, SCHMIDT
THERMOPOWER METHOD FOR CHEMICAL COMPOSITION AND INHOMOGENEITY MEASUREMENTS IN AMORPHOUS Ni-P SAMPLES

Tungarian Academy of Sciences CENTRAL RESEARCH INSTITUTE FOR PHYSICS 


\title{
THERMOPOWER METHOD FOR CHEMICAL COMPOSITION AND INHOMOGENEITY MEASUREMENTS IN AMORPHOUS Ni-P SAMPLES
}

\author{
L. Varga*, K. Tompa and T. Schmidt** \\ Central Research Institute for Physics \\ H-1525 Budapest 114, P.O.B. 49, Hungary \\ *On leave from the Institute for Welding and \\ Materials Testing, Timisoara, Romania. \\ **Csepel Iron and Metal Works, H-1751 Budapest, \\ Hungary
}

Submitted to Phys. Stat. Solidi 


\section{ABSTRACT}

Thermopower measurements around room temperature were carried out as a function of phosphorus content on $\mathrm{Ni}_{100-\mathrm{x}_{\mathrm{x}}}(\mathrm{x}=10-23)$ amorphous alloys prepared by electroless, electroplating and rapid quenching methods. It was found that thermopower increases monotonically with P content from negative to positive values, changing sign at about 15 ato of $P$. A concentration change of about 1 ato $P$ corresponds to $0.5 \pm 0.1 \mu \mathrm{V} / \mathrm{K}$ change in thermopower. A method is given, based on a simple thermoelectric probe, to check the inplane chemical homogeneity of the samples prepared by different techniques. The rapid quenched ribbons were found to be homogeneous, on the other hand inhomogeneities were found in the electroless and electroplated samples depending on the experimental circumstances.

АННОТАЦИЯ

На аморфных образцах $\mathrm{Ni}_{100-\mathrm{x}_{\mathrm{x}}}(\mathrm{x}=10-23)$, полученных путем химического осаждения, электролиза и јыстрого охлаждения, проводились измерения термонапряжения при комнатной температуре как функции от содержания Р. Найдено, что термонапряжение монотонно возрастает и изменяет знак при концентрации Р, близкой к 15 ат. жения примерно на 0,5 \pm 0,1 мкВ/К. Разработан простой метод исследования химической гомогенности вдоль плоскости образцов, полученных различным путем, основывающийся на использовании термоэлектрического зонда. Ленты, полученные быстрым охлаждением, оказались гомогенными, тогда как образцы, полученные химическим осаждением или электролизом, показали негомогенность, зависящую от условий получения.

\section{KIVONAT}

Termofeszültség méréseket végeztünk szobahômérsékleten kémiai leválasztással, elektrolizissel és gyorshütéssel elôállitott, amorf ${ }^{N i} 100-x^{P} x$

$(x=10-23)$ mintákon a foszfortartalom függvényében. Azt találtuk, hogy a termofeszültség monoton növekszik negativ értékektôl pozitiv értékek felé és közel 15 atơ P-nál vált elôjjelet. Közelitôleg 1 ator-os koncentrációváltozás $0,5 \pm 0,1 \mu \mathrm{V} / \mathrm{K}$ termofeszủltség változásnak felel meg. Egyszerü termoelektromos szondára alapozott módszert dolgoztunk ki a különbözố módon elõállitott minták sikbeli kémiai homogenitásának vizsgálatára. A gyorshütött szalagok homogéneknek bizonyultak, mig a kémiailag valamint elektrolizissel leválasztott minták az elôálilitási körülményektôl függố inhomogenitást mutattak. 


\section{INTRODUCTION}

Amorphous Ni-P alloys can be prepared by various techniques: chemical deposition [1,2], electrodeposition [3] and liquid quenching [4] if the phosphorus content is larger than 10-12 at: [5].

To study the properties of amorphous alloys, macroscopic homogeneous samples are required. We define macroscopic homogeneous samples on a scale larger than $0.1 \mu$. Macroscopic inhomogeneities may be produced by the variation of chemical composition, residual stresses, partial crystallization, etc. For example, Grewal et. al. [6] observed a lamellar structure for as-deposited electroless Ni-P alloys. These lamellae were believed to have resulted from periodic variation in the phosphorous content of the deposits between 9 and 11 wto.

The aim of this paper is twofold first, the study of room temperature thermopower as a function of $\mathrm{P}$ content in the case of Ni-P amorphous alloys; second, supposing that other effects can be neglected, the study of in-plane inhomogeneities of chemical composition of the samples prepared by different techniques. For this purpose a simple thermoelectric probe was developed for local room temperature thermopower measurements.

\section{SAMPLE PREPARATION}

Amorphous Ni-P samples were prepared by electroplating, chemical reduction and liquid quenching. The conditions for electrolitic deposition are described in Ref. [8] and for chemical reduction in Ref. [9]. Two types of solution were used for chemical reduction: one with $\mathrm{NiCl}_{2}$ (type $\mathrm{Cl}$ ) and another with $\mathrm{NiSO}_{4}$ (type $\mathrm{S}$ ). Ni-P ribbons were prepared by rapid quenching 
from the melt using the one-roller technique of Liebermann [10]. The glassy state of the alloys was checked by X-ray diffraction. The analysis of phosphorus concentration was performed by the photocalorimetric method. The thermopower measurements were done on as-received samples.

\section{EXPERIMENTAL METHODS}

A thermoelectric probe was designed for the local, relative thermopower measurements around room temperature. Figure 1 gives a simplified diagram of the probe. A thermoelectric force is set

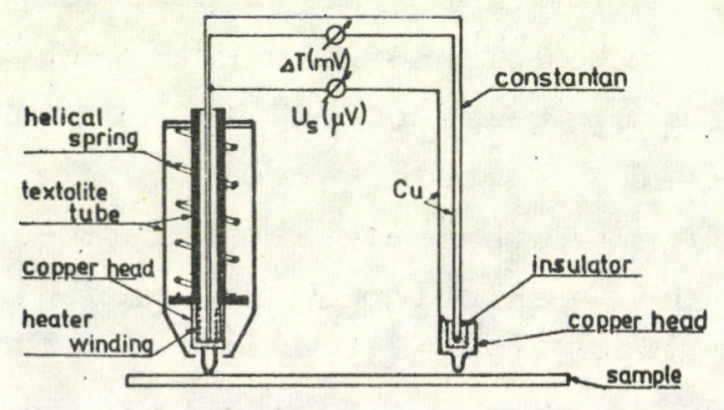

Fig. 1. The sketch of the termoelectric probe up between the heated and cold copper heads pressed against the sample and is measured with a Solartron $\mu \mathrm{V}$-meter. The heated copper head is fixed in a central textolite tube. This assembly slides freely in an outer casing. When the copper probe tip is pressed against the sample it recesses into the case and compresses a spring

which gives a constant load of approximately $2 \mathrm{~N}$. The resolution of the method is determined by the effective contact area, which depends on the tip geometry and the load applied. In our case the resolution is approximately $1 \mathrm{~mm}$. The location of the cold junction does not influence the measurements. The temperature difference $\Delta T$ was monitored on a digital mV-meter by a copper constantan thermocouple and drifted around $70{ }^{\circ} \mathrm{C}$ where the measurements were carried out, to avoid the temperature stability problem. The reproducibility of relative thermopower was better than $\pm 0.07 \mu \mathrm{V} / \mathrm{K}$. 


\section{RESULTS AND DISCUSSION}

Apart from some of the cl-type chemically deposited samples a monotonic almost linear relationship was found between the thermopower and phosphorus concentration for all the preparation techniques (Fig. 2). The relative thermopower measured against copper, $\mathrm{S}^{-\mathrm{S}_{\mathrm{Cu}}}$, became zero at about 19 at: of P. The absolute thermopower calculated for these measurements, using $\mathrm{S}_{\mathrm{Cu}}=1.7 \mu \mathrm{V} / \mathrm{K}$, changes sign at about 15 at: of P. At higher phosphorus concentration the absolute thermopower is positive in agreement with the measurements of cote [11]. The absolute thermopower was found to be linear in temperature around and above room temperature [9]. Deviation from linearity occur only around the crystallization temperature 550-600 K.

Regardless of the theoretical background of the thermo-

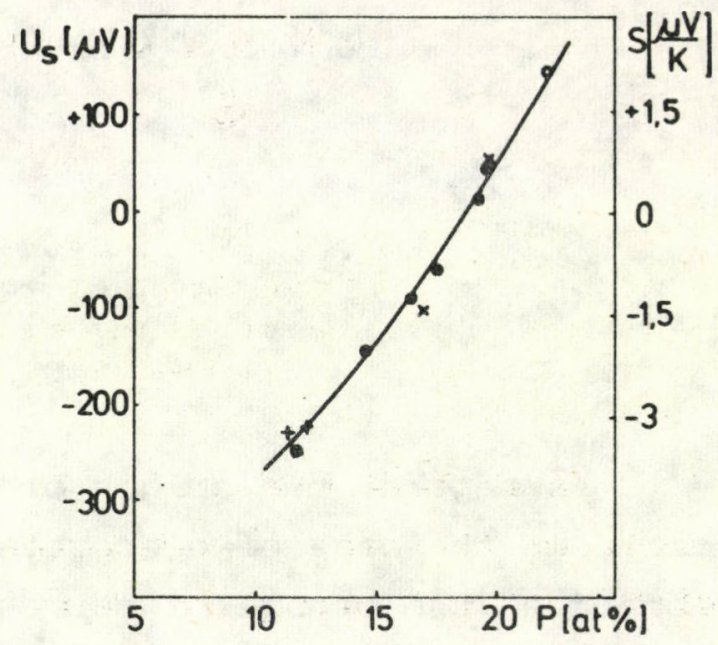

Fig. 2. Relative thermopower versus $P$ concentration in the as received state for: - electroless $S$ type, + electroless Cl type, x liquid quenched, - electropolated samples power [11-13], its correlation with the phosphorus concentration can be used to check the inhomogeneities in composition of the samples. This application is represented in Fig. 3 where the in-plane variation of the relative thermopower is shown in the case of an electroless and an electrodeposited sample. Using the $U_{S}-C p$ correlation shown in Fig. 2, a concentration change of about 1 at\% $\mathrm{P}$ corresponds to $0.5 \mu \mathrm{V} / \mathrm{K}$ change in thermopower. Accordingly, the total variation of $U_{S}$ represented in Fig. 3 corresponds to about 1 at\% change of $\mathrm{P}$ concentration around the nominal value. No variation of $U_{S}$ could be detected along the ribbons obtained by liquid quenching. 


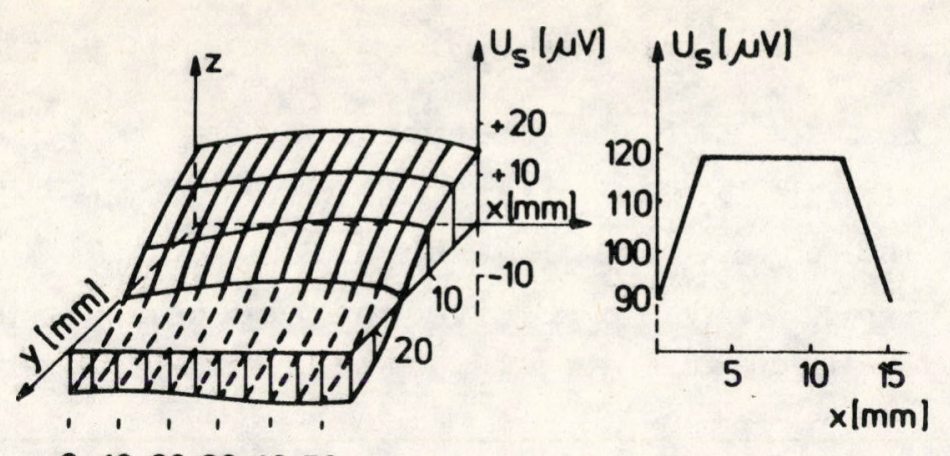

01020304050

(a.)

(b.)

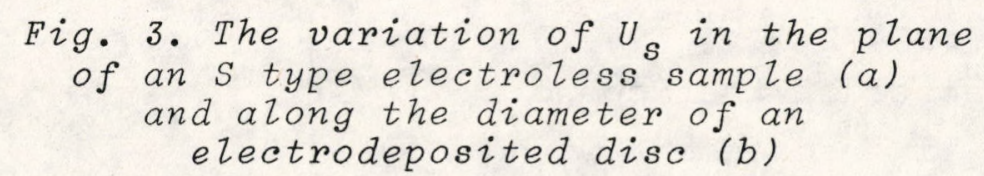

As regards the origin of the in-plane variation of composition, in the case of electrodeposited sample, one can suppose an effect of the change of current density at the edge of the support. To clarify this problem in the case of the electroless samples, some experiments were carried out using supports in the vertical and in the horizontal positions. Homogeneous samples were obtained from the upper side of the horizontal support. The
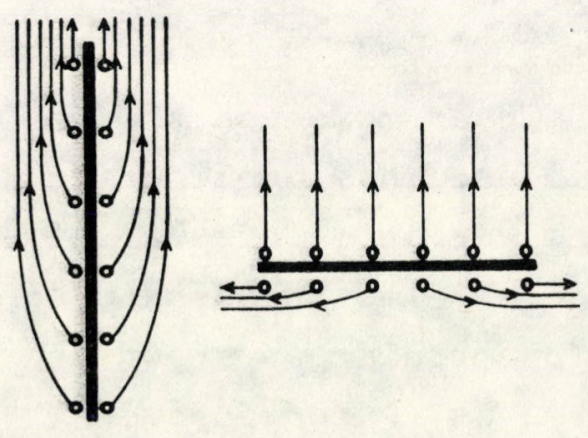

a.

b.

Fig. 4. Flow pattern of the $\mathrm{H}_{2}$ bubbles around the substrate in vertical (a) and horizontal (b) position sample depicted from the lower side of the horizontal support showed a composition variation, the $\mathrm{P}$ content decreased towards the edge of the sample. Inhomogeneities could be detected also on the samples depicted from both sides of the vertical support, namely the $\mathrm{P}$ content decreased upwards.

The same inhomogeneity exists in the liquid flow generated by $\mathrm{H}_{2}$ bubbles in the near vicinity of the deposition (Fig. 4). One can observe the following correlation: the higher the local liquid 
current caused by $\mathrm{H}_{2}$ bubbles the lower the local phosphorus content in deposition. This local mixing effect cannot be eliminated by an overall mixing of the liquid in the depositing container.

Thus, these measurements draw attention to the possibility of a small variation of $\mathrm{P}$ content even in an electroless deposit - which was previously assumed to be a homogeneous process - as a function of substrate geometry and its position in the depositing container.

Summarizing, by local relative thermopower measurements the chemical composition and inhomogeneities of the Ni-P deposition can be controlled. This correlation remains upon crystallization though some change can be detected relative to that obtained for amorphous samples. These measurements will be published elsewhere.

\section{REFERENCES}

[1] A.W. Goldenstein, W. Rostaker, F. Schossberger and G. Gutzeit, J. Electrochem. Soc. 104, (1957)

[2] A.H. Graham, R.W. Lindsay and H.J. Read, J. Electrochem. Soc. 112, 401 (1965)

[3] A. Brenner, D.E. Couch and E.K. Williams, Plating 37, 36 (1950)

[4] Y. Waseda, H. Okasaki, M. Naka and T. Masumoto, SCI. Rep. RITU A. vol. 26, $\mathrm{nr} .1,12$ (1976)

[5] A.W. Simpson and D.R. Bramley, phys. stat. sol. (b) 49,685 (1972)

[6] M.S. Grewal, S.A. Sastri and B.H. Alexander, Thermochimica Acta 14, 25 (1976)

[7] Y. Waseda, H. Okasaki, T. Masumoto, J. Mater. Sci. 12, 1929 (1977)

[8] I. Bakonyi, I. Kovács, L. Varga, T. Bagi, A. Lovas, E. Tóth-Kádár, K. Tompa, Conference on Metallic Glasses: Science and Technology, Budapest (June 30-July 4, 1980) Hungary 
[9] A. Cziráki, B. Fogarassy, I. Bakonyi, K. Tompa, T. Bagi, $\mathrm{z}$. Hegedüs, Fourth Int. Conf. on Liquid and Amorphous Metals, July 7-11, 1980, Grenoble, France

[10] H.H. Liebermann and C.D. Graham, IEEE Trans. Magn. 12, 921 (1976)

[11] P.J. Cote and L.V. Meisel, Phys. Rev. B2O, 3030 (1979)

[12] R.D. Barnard, Thermoelectricity in Metals and Alloys (Taylor and Francis, London, 1972)

[13] Soumen Basak, S.R. Nagel and B.C. Giessen, Phys. Rev. B21, 4049 (1980) 



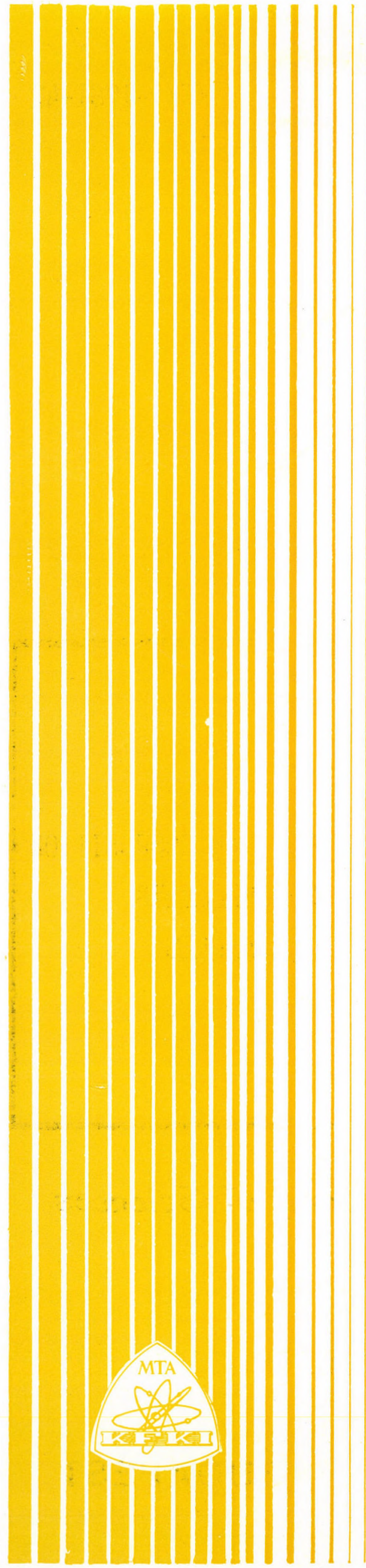

Kiadja a Központi Fizikai Kutató Intézet Felelôs kiadó: Kroó Norbert

Szakmai lektor: Konczos Géza Nyelvi lektor: Harvey Shenker Gépelte: Végvári Istvánné Példányszám: 500 Törzsszám: 81-324 Készült a KFKI sokszorositó üzemében Felelốs vezetô: Nagy Károly Budapest, 1981. május hó 